\title{
Protein Elicitor EsxA Induces Resistance to Seedling Blight and PR Genes Differential Transcription in Rice
}

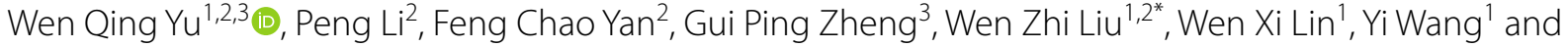
Zhi Qing Luo ${ }^{1}$

\begin{abstract}
Protein elicitors can induce plant systemic resistance to pathogens. In an earlier study, we cloned an EsxA gene from the plant growth-promoting rhizobacterium Paenibacillus terrae NK3-4 and expressed it in Pichia pastoris. In addition to being important for the pathogenicity of animal pathogens, EsxA can also induce an immune response in animals. While, we found the exogenously expressed EsxA has the activity of elicitor, which can trigger hypersensitive response and reactive oxygen species burst in leaves as well as enhanced rice plant growth. The effects of EsxA on seedling blight (Fusarium oxysporum) resistance and gene transcription, including pathogenesis-related (PR) genes in rice were evaluated. The germination rate was 95.0\% for seeds treated with EsXA and then inoculated with F. oxysporum, which was 2.8-times higher than that of F. oxysporum-infected control seeds that were not treated with EsXA (Con). The buds and roots of EsxA-treated seedlings were 2.4- and 15.9-times longer than those of Con seedlings. The plants and roots of seedlings dipped in an EsxA solution and then inoculated with F. oxysporum were longer than those of the Con seedlings. Theplant length, number of total roots, and number of white roots were respectively $23.2 \%$, 1.74-times, and 7.42-times greater for the seedlings sprayed with EsxA and then inoculated with F. oxysporum than for the Con seedlings. The EsxA induction efficiency (spray treatment) on seedling blight resistance was 60.9\%. The transcriptome analysis revealed 1137 and 239 rice genes with EsxA-induced up-regulated and down-regulated transcription levels, respectively. At $48 \mathrm{~h}$ after the EsxA treatment, the transcription of 611 and 160 genes was up-regulated and downregulated, respectively, compared with the transcription levels for the untreated control at the same time-point. Many disease resistance-related PR genes had up-regulated transcription levels. The qPCR data were consistent with the transcriptome sequencing results. EsxA triggered rice ISR to seedling blight and gene differential transcription, including the up-regulated transcription of rice PR genes. These findings may be relevant for the use of EsXA as a protein elicitor to control plant diseases.
\end{abstract}

Keywords: Protein elicitor, EsxA, Induced systemic resistance, Transcriptome, Pathogenesis-related protein, Signal transduction

\footnotetext{
*Correspondence: liuwz19801005@sina.com

${ }^{1}$ College of Life Sciences, Shangrao Normal University, Shanrao 334001,

Jiangxi, China

Full list of author information is available at the end of the article
}

\begin{abstract}
Background
Elicitors can induce plant resistance via signal recognition, signal transduction, and defense gene regulation. Protein elicitors are the most important type of elicitors that activate host plant defense responses (Shen et al. 2019) to enhance disease resistance (Ruiz et al. 2018; Mao et al. 2010; Wang et al. 2012; Qiu et al. 2009) and insect resistance (Li et al. 2020). They also stimulate
\end{abstract}

Springer Open

(c) The Author(s) 2021. Open Access This article is licensed under a Creative Commons Attribution 4.0 International License, which permits use, sharing, adaptation, distribution and reproduction in any medium or format, as long as you give appropriate credit to the original author(s) and the source, provide a link to the Creative Commons licence, and indicate if changes were made. The images or other third party material in this article are included in the article's Creative Commons licence, unless indicated otherwise in a credit line to the material. If material is not included in the article's Creative Commons licence and your intended use is not permitted by statutory regulation or exceeds the permitted use, you will need to obtain permission directly from the copyright holder. To view a copy of this licence, visit http://creativecommons.org/licenses/by/4.0/. 

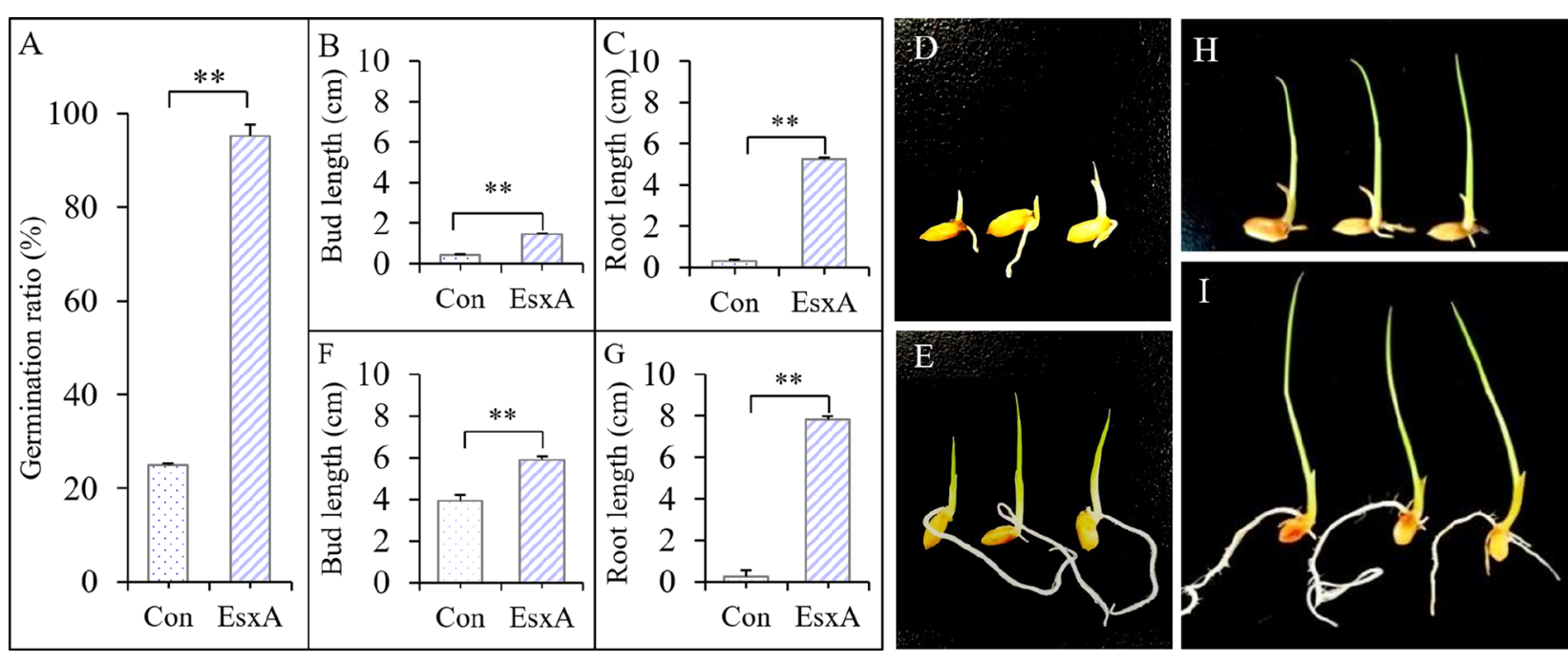

Fig. 1 Effects of protein elicitor EsXA on the germination and growth of rice under seedling blight (Fusarium oxysporum) stress (seed-dipping treatment). Bar diagrams $\mathbf{A}, \mathbf{B}, \mathbf{C}, \mathbf{D}$ and $\mathbf{E}$ present the results at 4 days after rice was challenged with Fusarium oxysporum; $\mathbf{F}, \mathbf{G}, \mathbf{H}$ and $\mathbf{I}$ represent 8 days after rice was challenged with F. oxysporum, respectively, with "Con" representing the control treatment (without EsxA) and "EsxA" representing the EsxA treatment $\left({ }^{*} P<0.01\right)$

plant metabolism to regulate plant growth (Darwati et al. 2018). Recent research on the mechanism underlying elicitor-induced plant stress resistance revealed that pathogenesis-related (PR) proteins may be elicitor receptors that directly or indirectly bind to elicitors, after which they activate a series of downstream defenserelated signal transduction pathways, and trigger plant broad-spectrum induced systemic resistance (ISR) to diseases (Liu et al. 2018; Li et al. 2019).

Early secreted antigenic target of $6 \mathrm{kDa}$ (ESAT-6) is encoded by the EsxA gene, which belongs to the WXG super family. This protein, which was identified in animal pathogens (Pollock and Andersen 1997; Schulthess et al. 2012; Ma et al. 2015), functions in the Type VII secretion system. It has been studied as a virulence factor for bacterial pathogens, and its importance for pathogenicity has been confirmed (Berthet et al. 1998; Ulrichs et al. 1998). However, EsxA is not a simple virulence factor. In addition to being important for the pathogenicity of animal pathogens, it can also induce an immune response in animals (Zhou et al. 2013).

In an earlier study, we cloned an EsxA gene from the plant growth-promoting rhizobacterium Paenibacillus terrae NK3-4 and expressed it in Pichia pastoris, with the secreted protein inducing a hypersensitive response (HR) and reactive oxygen species (ROS) burst in leaves as well as enhanced rice plant growth (Yu et al. 2021). To further assess whether EsxA can induce plant disease resistance, we used various methods to treat rice with EsxA to evaluate its effect on rice resistance to seedling blight. Transcriptome sequencing and quantitative realtime PCR (qPCR) analyses were combined to investigate the transcription of rice genes, including PR genes, to clarify the mechanism underlying EsxA-induced plant disease resistance at the transcriptional level. The resulting data may form the basis of future research on the role of receptor proteins in cells during interactions between EsxA and plants.

\section{Results}

EsxA Induction Effect on Rice Seedling Blight Resistance EsxA Induction Effect After the Seed-Dipping Treatment

At 4 days after the inoculation with the $F$. oxysporum spore suspension, only $25.0 \%$ of the Con seeds (i.e., not treated with EsxA) germinated, whereas $95.0 \%$ of the EsxA-treated seeds germinated, with a germination rate 2.8-times higher than that of the Con seeds $(F=1622.49$, $P<0.001$ ) (Fig. 1A). The bud length and the root length of the EsxA-treated rice were 2.4-times $(F=4800.50$, $P<0.001$ ) (Fig. 1B; D compared with E) and 15.9-times $(F=1095.200, P<0.001)$ (Fig. $1 \mathrm{C}$; D compared with $\mathrm{E})$ greater than the corresponding lengths of the Con rice, respectively. After another 4-day incubation, no newly germinated seed in both treatment, while the EsxA rice bud length was longer than Con $(F=88.506, P=0.001)$ (Fig. 1F; H compared with I). while the Con rice exhibited obvious seedling blight symptoms, with retarded bud and root growth and yellowish-brown decaying roots (Fig. $1 \mathrm{H}$ ), because of the roots roted, the root length shorter than that before 4 days (Fig. 1, C comared with 


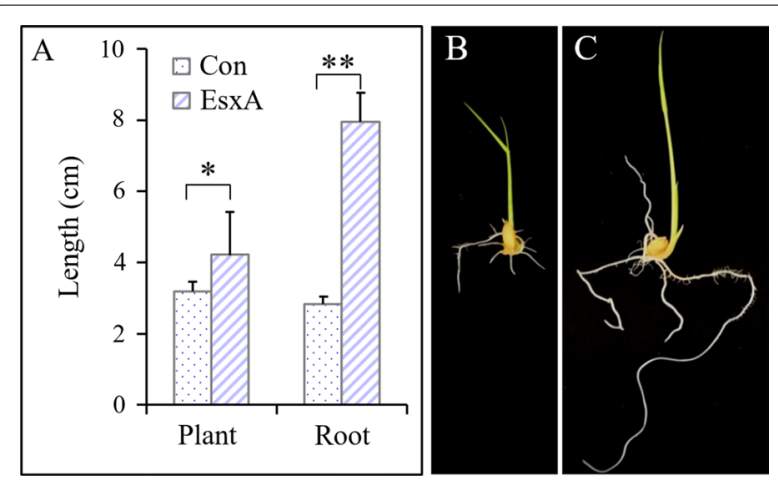

Fig. 2 Effects of protein elicitor EsxA on the plant and root length of rice under seedling blight (Fusarium oxysporum) stress (seedling-dipping treatment). Bar diagram $\mathbf{A}$ presents the results at 5 days after rice was challenged with Fusarium oxysporum, with "Con" representing the control treatment (without EsxA) and "EsXA" representing the EsxA treatment; $\mathbf{B}$ and $\mathbf{C}$ represent "Con" and "EsXA" respectively $\left.\left({ }^{*} P<0.05,{ }^{* *} P<0.01\right)\right)$

G of Con; H compared with D). In contrast, the roots of EsxA-treated rice continued to grow, and remained white (Fig. 1I), meanwhile, the root length of EsxA rice was longer than that of Con rice $(F=821.884, P<0.001)$ (Fig. 1G; H compared with I). Thus, the seed-dipping EsxA treatment promoted the growth of rice seedlings infected by $F$. oxysporum, with minimal disease symptoms. At 4th day after infected by $F$. oxysporum, the induction efficiency for the germination rate, bud length, and root length was $280.7 \%, 238.5 \%$, and $493.3 \%$, respectively. And the induction efficiency for the bud length and root length was $50.9 \%$ and $2879.6 \%$ at 8 days infected by $F$. oxysporum, respectively.

\section{EsxA Induction Effect After the Seedling-Dipping Treatment}

After a $48-\mathrm{h}$ treatment with EsxA $(100 \mu \mathrm{g} / \mathrm{mL})$ and a 5-day incubation following an inoculation with $F$. oxysporum, the bud length and root length of the EsxA-treated rice were respectively $32.1 \%(F=17.344, P=0.014)$ and 1.8 -times $(F=24.324, P=0.008)$ greater than the corresponding lengths of the Con rice (Fig. 2A; compared $\mathrm{B}$ with $\mathrm{C}$ ). The induction efficiency for the bud length and root length was $32.1 \%$ and $179.8 \%$, respectively. These results indicated that the seedling-dipping treatment with EsxA promoted the growth of rice seedlings infected with F. oxysporum.

\section{EsxA Induction Effect After the Seedling-Spraying Treatment}

At $48 \mathrm{~h}$ after the EsxA treatment, the plant height, number of roots, and number of white roots were respectively $17.5 \%(F=9.491, P=0.015), 2.0$-times $(F=192.753$, $P<0.001)$, and 58.0\% $(F=68.016, \quad P<0.001)$ greater for the EsxA-treated rice than for the Con rice. The EsxA treatment had no significant effect on root length (Fig. 3A; C compared with D). At 7 days after the inoculation with $F$. oxysporum, the plant height, number of roots, and number of white roots were respectively $23.2 \%$ ( $F=48.790, P<0.001)$, 1.74-times $(F=38.018, P<0.001)$,

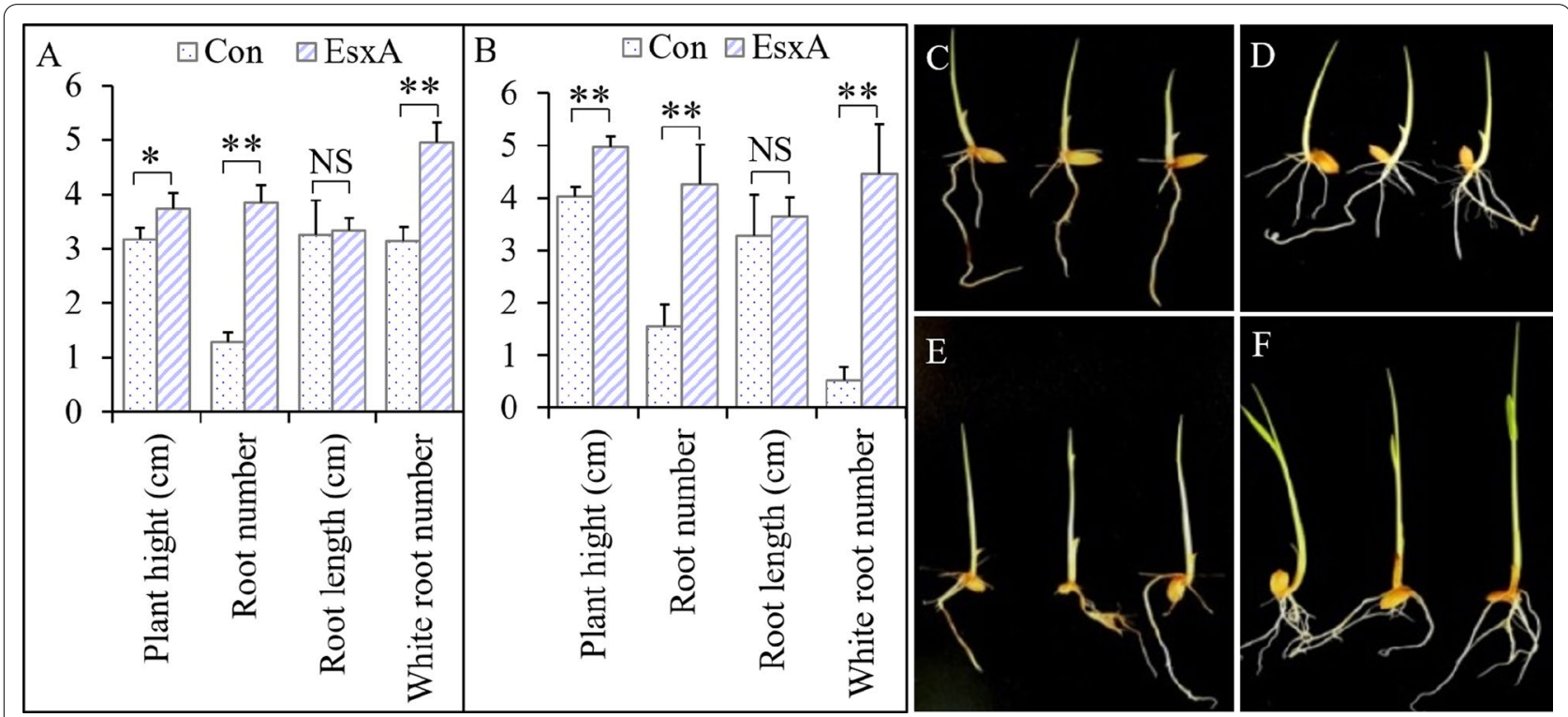

Fig. 3 Effects of protein elicitor EsxA on the growth and performances of rice udner seedling blight (Fusarium oxysporum) stress (seedling-spraying treatment, 7 days). A, C, and $\mathbf{D}: 48 \mathrm{~h}$ after the EsxA treatment; $\mathbf{B}, \mathbf{E}$, and $\mathbf{F}: 7$ days after the inoculation with Fusarium oxysporum, with $\mathbf{C}$ and $\mathbf{D}$ representing control (Con) seedlings (without EsxA) and $\mathbf{E}$ and $\mathbf{F}$ representing seedlings sprayed with EsxA. The number of roots was determined based on roots longer than $1 \mathrm{~cm}$; the number of white roots includes roots shorter than $1 \mathrm{~cm}\left({ }^{*} P<0.05,{ }^{* *} P<0.01\right)$ 

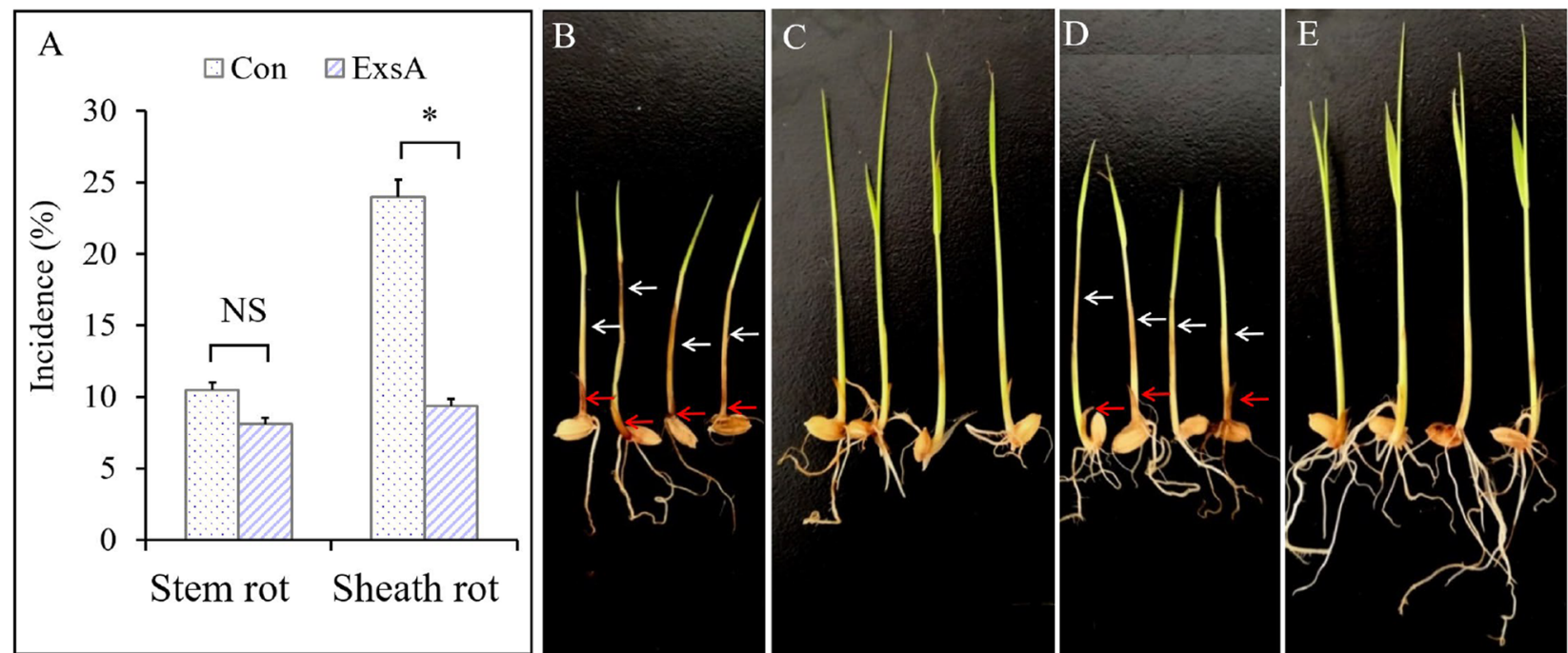

Fig. 4 Effects of protein elicitor EsXA on the incidence of rice seedling blight (seedling-spraying treatment, 14 days). A representing the incidence of stem rot and sheath rot respectively, $\mathbf{B}$ and $\mathbf{C}$ : control (Con) seedlings (sprayed with bovine serum albumin), D and E: EsxA-treated plants, with B and $\mathbf{D}$ representing the plants exhibiting stem rot (white arrows) and sheath rot (red arrows) symptoms; $\mathbf{C}$ and $\mathbf{E}$ representing the plants exhibiting sheath rot symptoms ( ${ }^{*} P<0.05$; NS: not significant)

and 7.42-times $(F=63.888, P<0.001)$ greater for the EsxA-treated rice than for the Con rice (Fig. 3B; E compared with F). The results implied that the EsxA treatment alleviated the adverse effects of $F$. oxysporum on rice growth.

At 7 days after the inoculation with $F$. oxysporum, the Con roots were yellow and the number of white roots decreased by $83.1 \%$ compared with that before the inoculation $(F=214.554, P<0.001)$. In contrast, there was no significant decrease in the number of white roots for the EsxA-treated rice inoculated with $F$. oxysporum $(F=0.966, P=0.354)$ (Fig. 3$)$. These results indicated that the EsxA spray-treatment promoted rice seedling growth and development, while also significantly decreasing the detrimental effects of $F$. oxysporum on seedling growth.

At 14 days after the inoculation with $F$. oxysporum, the seedling blight incidence of EsxA-treated rice was significantly lower than that of Con rice. More specifically, the incidence of sheath rot and stem rot among the Con plants was $10.5 \%$ and $24.0 \%$, respectively, for a seedling blight incidence of $34.5 \%$. The incidence of sheath rot and stem rot among the EsxA-treated plants was $8.1 \%$ and $9.4 \%$, respectively, for a seedling blight incidence of 17.5\%. The EsxA treatment significantly decreased the incidence of stem $\operatorname{rot}(F=5.400, P=0.032)$ and the overall seedling blight incidence $(F=8.455, P=0.009)$. The EsxA induction efficiency on rice sheath rot and stem rot resistance was $13.8 \%$ and $60.9 \%$, respectively (Fig. 4A). The EsxA treatment decreased the incidence and severity of rice seedling blight (Fig. 4, B compared with D).
Additionally, the roots of EsxA-treated rice grew significantly better than the Con roots, with whiter roots, longer roots, and more roots (Fig. 4, C compared with E). Furthermore, the Con roots produced a strong odor similar to rotting pear, which is a hallmark characteristic of seedling blight, whereas the roots of the EsxA-treated rice were odorless.

\section{Effects of EsxA on the Rice Transcriptome Effects of EsxA on Gene Transcription in Rice}

The rice transcriptome was sequenced at the two-leaf stage. Specifically, the following samples were analyzed: rice before the EsxA treatment (Con0), rice at $48 \mathrm{~h}$ after the EsxA treatment (E48), and control rice (without EsxA treatment) at $48 \mathrm{~h}$ (Con48). The RNA-seq raw data of nine samples (three biological replicates in each treatment) were submitted to NCBI bioSample database (accessions: SAMN19404905-SAMN19404913). A total of 36,844 genes and 43,397 transcripts were detected in the rice transcriptome library, including 14,029 new transcripts. A comparison between Con 0 and E48 revealed 1376 differentially transcribed genes (i.e., transcription levels differed by more than 2 times, the same belows), of which 1137 were up-regulated and 239 were down-regulated in the EsxA-treated rice (Fig. 5A). A comparison between E48 and Con48 detected 771 differentially transcribed genes, of which 611 were up-regulated and 160 were down-regulated in the EsxA-treated rice (Fig. 5B). Thus, EsxA modulated the transcription of many rice 


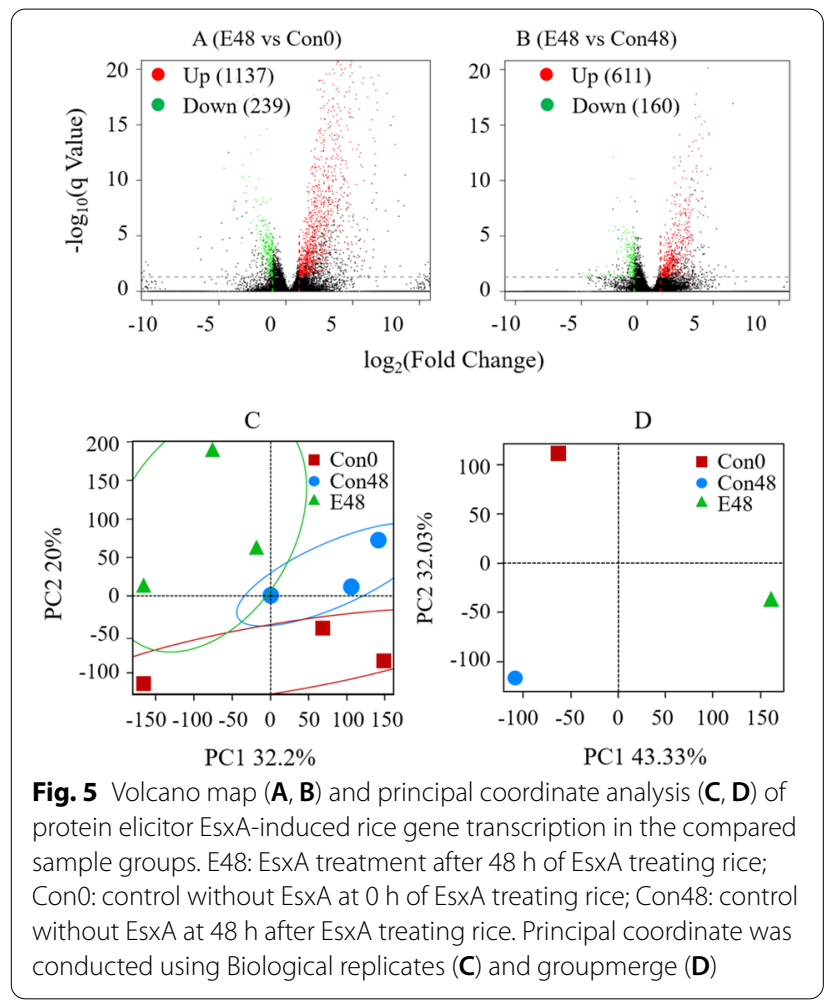

genes, with substantially more up-regulated genes than down-regulated genes.

The principal componet analysis of rice gene transcription indicated that E48 was displaced along the PC1 axes when compared with Con 0 and Con 48 (Fig. 5C, D). Additionally, Con 48 and E48 were displaced along the PC2 axis when compared with Con0. The three EsxA treatment groups formed three spatially clusters. These results suggested that rice gene transcription induced by EsxA.

\section{Functional Analysis of EsxA-induced Differentially Transcribed Genes}

The gene ontology (GO) annotations indicated that EsxA induced the differential transcription (compared with Con0) of genes in 2,612 functional groups. One of the most significantly enriched functional groups was GO: 2000022 [regulation of jasmonic acid (JA)-mediated signaling pathway]. The three enriched functional groups with the most genes were GO: 0071944 (cell periphery), GO: 0005886 (plasma membrane), and GO: 0006950 (response to stress) (Fig. 6A). The comparison with Con48 indicated that the EsxA treatment induced the differential transcription of genes in 2100 functional groups. The most significantly enriched functional groups were GO: 0031408 (oxylipin biosynthetic process) and GO: 0031407 (oxylipin metabolic process). The enriched functional groups with the most differentially transcribed genes were GO: 0043167 (ion binding), GO: 0046872 (metal ion binding), and GO: 0043169 (cation binding) (Fig. 6B). Genes in 11 functional groups were identified as differentially transcribed in both the $\mathrm{E} 48$ versus Con0 and $\mathrm{E} 48$ versus Con 48 comparisons (Fig. 6A, B, classification numbers in red).
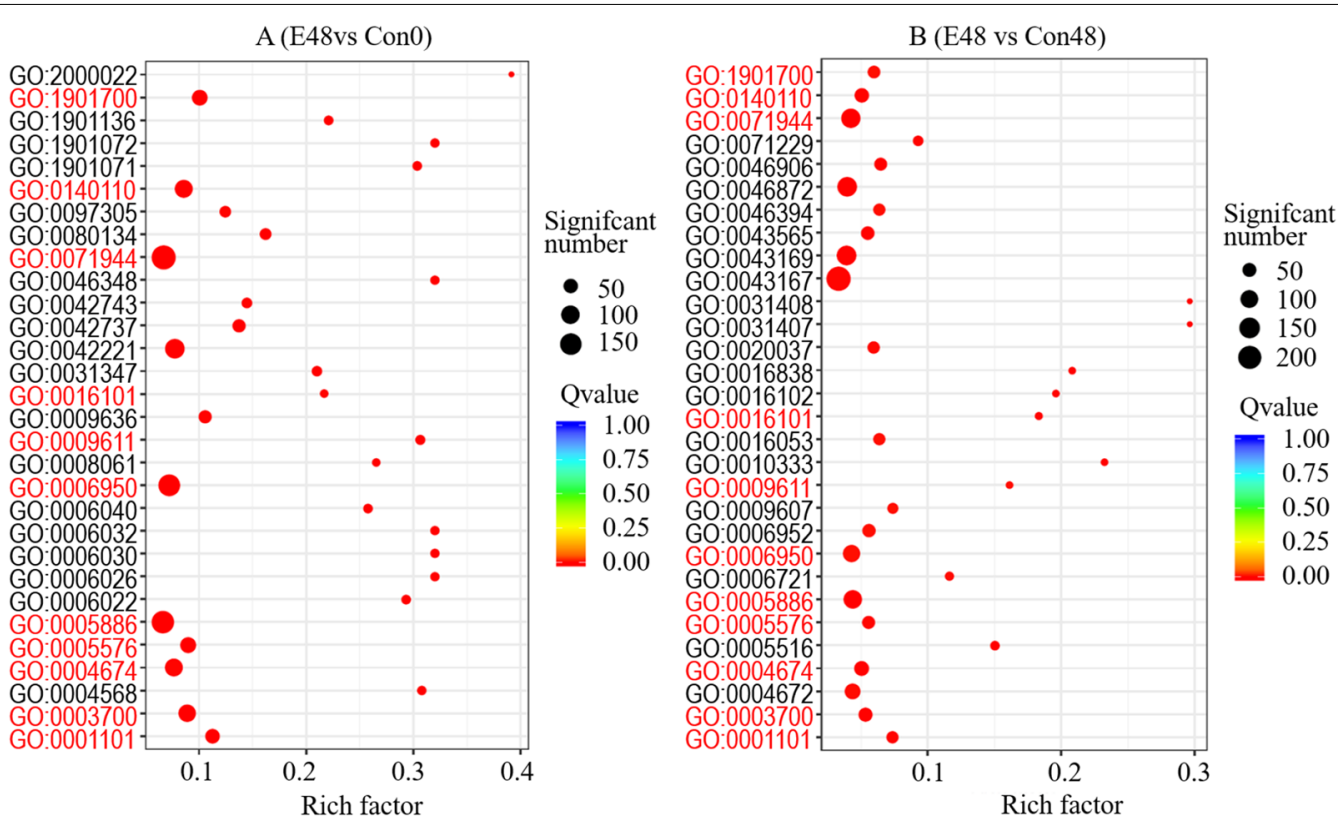

Fig. 6 Scatter diagram of GO classification of protein elicitor EsxA-induced differentially transcribed genes in rice 

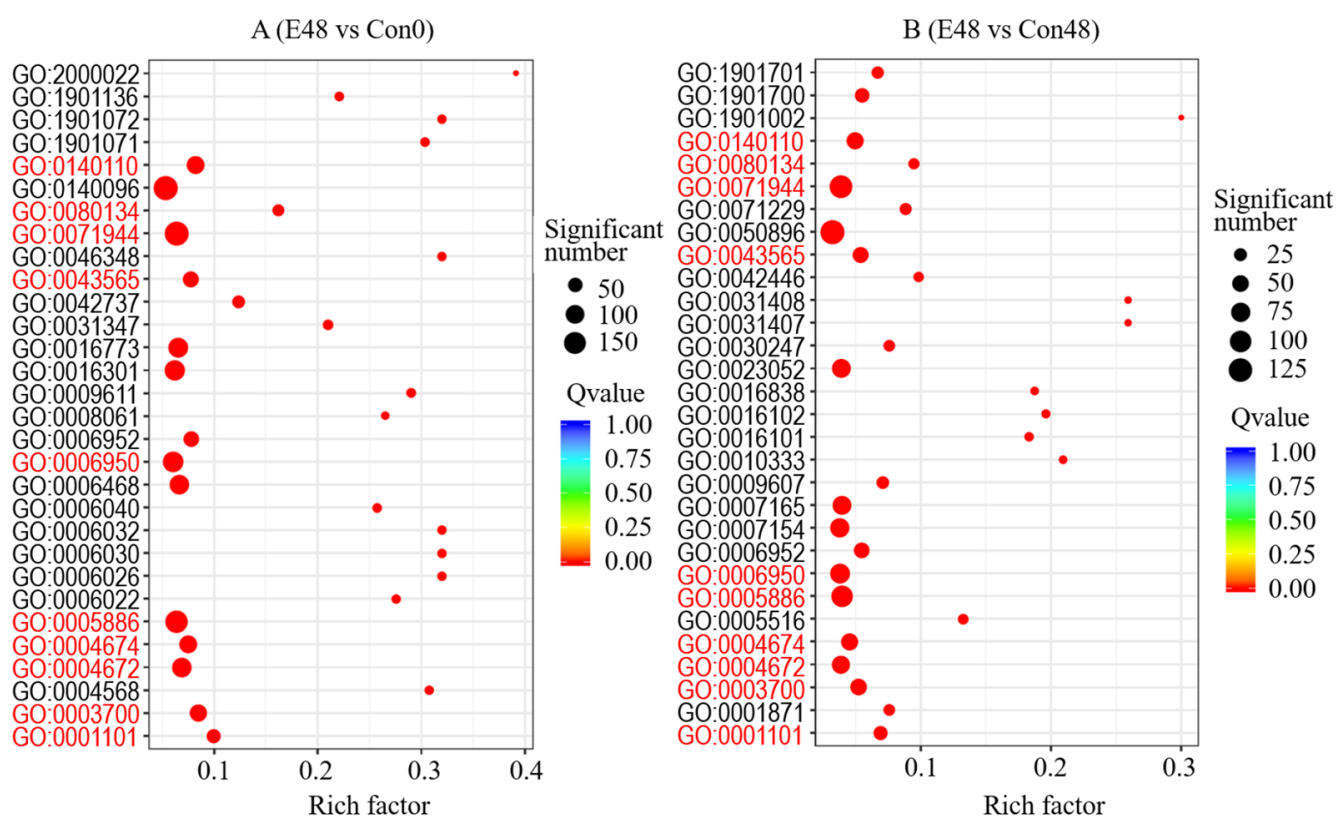

Fig. 7 Scatter diagram of GO classification of protein elicitor EsxA-induced up-regulated genes in rice

\section{Functional Analysis of EsxA-induced Up-regulated Genes}

The GO annotations revealed that EsxA up-regulated the transcription of genes in 2244 functional groups (E48 vs. Con0). One of the most significantly enriched functional groups was GO: 2000022 (regulation of JAmediated signaling pathway). The four enriched functional groups with the most genes were GO: 0140096 (catalytic activity, acting on a protein), GO: 0005886 (plasma membrane), GO: 0071944 (cell periphery), and GO: 0006950 (response to stress) (Fig. 7A). Compared with Con48, the EsxA treatment up-regulated the transcription of genes in 1807 functional groups. The most significantly enriched functional group was GO: 1901002 (positive regulation of response to salt stress), followed by GO: 0031408 (oxylipin biosynthetic process) and GO: 0031407 (oxylipin metabolic process). The three enriched functional groups with the most genes were GO: 0050896 (response to stimulus), GO: 0071944 (cell periphery), and GO: 0005886 (plasma membrane) (Fig. 7B). Furthermore, genes in 12 functional groups were identified as up-regulated in both the E48 versus Con0 and E48 versus Con48 comparisons (Fig. 7A, B; classification numbers in red).

The genes with EsxA-induced up-regulated transcription levels (E48 vs. Con48) were associated with the cell periphery, plasma membrane, transcription regulator activity, calmodulin binding, signal transduction, defense responses, hormone responses [including abscisic acid (ABA) and JA responses], chitin response, ethanol response, response to oxygen-containing compounds, ABA-activated signaling pathways, JA-mediated signaling pathway regulation, diterpene biosynthesis process, protein phosphorylation, cell communication, and chitinase activity. These functions may contribute to the disease resistance of rice.

\section{Disease Resistance-related Genes with EsxA-induced Up-regulated Transcription Levels}

The genes with EsxA-induced up-regulated transcription levels included genes related to disease resistance. At $48 \mathrm{~h}$ after the EsxA treatment, the transcription levels of genes encoding mitogen-activated protein kinase 2 (MAPK2), NPK1-related PK2, WRKYs, TIFYs, chitinases, PR10, XB15, PODS, PAL, ERF, and MYBS were significantly up-regulated (E48 vs. Con0). The transcription levels of these genes were also detected as up-regulated in the E48 versus Con48 comparison, but the up-regulated transcription level was less than that in the E48 versus Con0 comparison. Additionally, the transcription levels of 12 genes were up-regulated over time in rice that was not treated with EsxA (Con48 vs. Con0); however, the extent of the up-regulation was less than that revealed by the E48 versus Con 0 comparison. The PR genes with EsxA-induced up-regulated transcription levels encode the following disease resistance-related proteins: NPK1related PK, WRKY71, TIFY11A, PR8, chitinase 1, chitinase 3, chitinase 8, root-specific Oryza sativa PR10, root-specific rice PR10, root-specific OsPR10a, POD22, POD62, POD22.3, and MYB2 (E48 compared with Con0 and Con48). These results indicated that a few of these genes (12) were up-regulated over time even without 
EsxA induction (Con48 vs. Con0), while more genes (51) were up-regulated over time only with EsxA induction (E48 vs. Con0), which also up-regulated at the same point in time, compared with control without EsxA treatment (E48 vs. Con48), but no one had higher fold change than that of E48 versus Con0 (Table 1).

\section{Verification of Up-regulated Transcription by $q P C R$}

The qPCR data for the genes encoding PR2, PR8, WRKY45, POD22, PAL, NPK1-related PK, AOS, NPR1like gene 4, and ethylene response factor 104 (ERF104) were consistent with the transcriptome sequencing results (Fig. 8).

\section{Discussion}

Bases on our studies on EsxA, we believe it a protein elicitor that can trigger ISR in plant, including rice seedling blight and rice blast (Yu et al. 2021a). While other researchers suggest that EsxA can induce immunogenic activity of animal to bacterial diseases (Zhou et al. 2013; Hoang et al. 2013; Yi et al. 2021). Even though there may be differences of diseases that caused by bacterial and fungal pathogens in plant or animal, but the animal's immunity is similar to plant systemic resistance, they both enhancing organism resistance to some diseases. And we believe that EsxA can trigger ISR in rice based on the transcriptome sequencing results and our prevous study (Yu et al. 2021a).

Plants stimulated by protein elicitors will produce a series of defense responses (e.g., oxidative burst, HR, and nitric oxide accumulation) (Gabriel et al. 2015; Foissner 2000), which subsequently activate the disease resistancerelated metabolic activities involving the JA, ethylene, and aABA signaling pathways. Moreover, there is "crosstalk" among the various signaling pathways. For example, the elicitor may interact with JA esters, ethylene signaling pathways, and ROS. This cross-talk integrates multiple signaling pathways and transcription factors (Cheng et al. 2018). The above-mentioned signaling components affect the elicitor signaling network at the transcriptional and metabolic levels to influence plant secondary metabolism (Zhao et al. 2005; Cheplick et al. 2018). The affected secondary metabolites will further regulate plant growth and stress resistance. Most researchs indicates that the elicitor induced resistance is mostly systemic resistance (Wang et al. 2021).

On the basis of the transcriptome sequencing data and the results of our previous studies (Yu et al. 2021b), we speculate that EsxA helps plants establish the first defense response by inducing the ROS burst and HR and by activating the transcription of cell structure-related genes to strengthen the cell wall (e.g., increased PAL levels) (Table 1, Fig. 8). Moreover, EsxA also interacts with membrane receptors, which then activate transcription factors, including WRKYs. These WRKY transcription factors then interact with NPK1-related PK to increase the transcription of downstream defense genes (e.g., PR1, PR2, PR8, and POD genes) (Table 1, Fig. 8) and protein phosphorylation, resulting in the formation of second messengers. Among which, POD activity was confirmed increased in EsxA treated rice plant (Yu et al. 2021b). The amplified signal will induce the ROS burst in other cells via signal transduction pathways. These changes can further regulate salicylic acid-mediated systemic acquired resistance or $\mathrm{JA} / \mathrm{C}_{2} \mathrm{H}_{4}$-mediated induced systemic resistance, which ultimately triggers disease resistance-related responses.

Genes encoding EsxA have been commonly detected in the genomes of plant growth-promoting rhizobacteria belonging to the genus Paenibacillus, including $P$. terrae NK3-4 (Yu 2019). However, EsxA in Paenibacillus species has not been functionally characterized. The results described herein indicate that EsxA regulates the transcription of plant PR genes via molecular interactions to initiate defense-related metabolism, leading to disease resistance. To clarify the mechanism underlying EsxAinduced plant disease resistance and lay the foundation for using EsxA to protect plants from diseases, future studies will be performed to confirmation our hypothesis as the following. First, the molecular interactions between EsxA and host plants at the level of transcription and the post-transcriptional regulation of downstream genes encoding proteins (e.g., PR proteins) that interact with transcription factors should be explored, these interactions increase plant disease resistance through signal transduction pathways that regulate salicylic acid and/ or JA defense-related metabolism. Second, EsxA receptor proteins will need to be identified and the binding of EsxA to the receptor protein (or receptor-like protein) should be confirmed in protein interaction analyses. The binding of EsxA to the receptor regulates PR gene transcription or downstream signal transduction to enhance plant disease resistance. Third, an es $x A$-transgenic rice will be constructed and compared with wild varieties to detect the difference of disease resistance, which will also provide materials for rice resistance breeding.

\section{Conclusions}

The EsxA treatment induced seed germination, increased seedling vigor, promoted seedling growth, and enhanced seedling blight resistance in response to the $F$. oxysporum infection. The transcriptome analysis combined with qPCR proved that EsxA induced the differential transcription of rice genes, including the up-regulated transcription of a series of PR genes. These findings may be relevant for the use of EsxA as a protein elicitor to control 
Table 1 Information regarding disease resistance-related genes with EsxA-induced up-regulated transcription levels

\begin{tabular}{|c|c|c|c|c|c|}
\hline \multirow[t]{2}{*}{ Protein name } & \multirow[t]{2}{*}{ Description (gene ID) } & \multicolumn{3}{|c|}{$\log _{2}($ Fold Chang) $(P<0.05)$} & \multirow[t]{2}{*}{ References } \\
\hline & & $\begin{array}{l}\text { E48 } \\
\text { versus } \\
\text { Con0 }\end{array}$ & $\begin{array}{l}\text { E48 } \\
\text { versus } \\
\text { Con48 }\end{array}$ & $\begin{array}{l}\text { Con48 } \\
\text { versus } \\
\text { Con0 }\end{array}$ & \\
\hline MAPK & $\begin{array}{l}\text { Multiple stress responsive MAP kinase } 2 \\
\text { (Os03g0285800) }\end{array}$ & 3.46 & 2.68 & - & Song and Goodman (2002), Hur and Kim (2014) \\
\hline MAPKKK & MAPK kinase kinase 6 (Os01g0699500) & 3.87 & 3.64 & - & Ma et al. $(2017,2021)$ \\
\hline NPK1-related PK & NPK1-related protein kinase (Os01g0699600) & 5.59 & 3.56 & 2.03 & Savatin et al. (2014) \\
\hline \multirow[t]{3}{*}{ ERF } & $\begin{array}{l}\text { Ethylene response factor (ERF) } 104 \\
\text { (Os08g0474000) }\end{array}$ & 5.79 & 4.35 & - & \multirow[t]{3}{*}{ Pré et al. (2008), Tripathi et al. 2020) } \\
\hline & ERF130 (Os05g0497200) & 2.86 & 1.85 & - & \\
\hline & ERF91 (Os02g0654700) & 2.91 & 1.99 & - & \\
\hline \multirow[t]{10}{*}{ WRKY } & WRKY1 (Os01g0246700) & 3.16 & 1.98 & - & Yang et al. (2009), Molan and El-Komy (2010) \\
\hline & WRKY21 (Os01g0821600) & 4.73 & 3.21 & - & Zhao et al. (2019) Zhou et al. (2008) \\
\hline & WRKY24 (Os01g0826400) & 4.39 & 2.89 & - & Yokotani et al. (2018) \\
\hline & WRKY28 (Os06g0649000 & 4.82 & 3.72 & - & Meng and Wise (2012), Chujo et al. (2013) \\
\hline & WRKY45 (Os05g0322900) & 3.52 & 2.68 & - & Shimono et al. (2007), Inoue et al. (2013) \\
\hline & WRKY53 (Os05g0343400) & 2.04 & 1.29 & - & Miao and Zentgraf. (2007), Hu et al. (2012) \\
\hline & WRKY62 (Os09g0417800) & 3.04 & 2.27 & - & Liu et al. (2016) \\
\hline & WRKY70 (Os05g0474800) & 5.10 & 3.49 & - & $\begin{array}{l}\text { Hu et al. (2012), Li et al. (2004), Ülker et al. (2007), } \\
\text { Knoth et al. (2007) }\end{array}$ \\
\hline & WRKY71 (Os02g0181300) & 3.85 & 1.90 & 1.95 & Liu et al. (2007) \\
\hline & WRKY79 (Os03g0335200) & 6.08 & 4.05 & - & Fu et al. (2017) \\
\hline \multirow[t]{3}{*}{ TIFY } & TIFY11A (Os03g0180800) & 4.57 & 2.39 & 2.18 & Ye (2011) \\
\hline & TIFY11B (Os03g0181100) & 3.70 & 2.74 & - & Ye (2011) \\
\hline & TIFY11E (Os10g0391400) & 4.68 & 4.21 & - & Ye et al. (2009) \\
\hline \multirow[t]{5}{*}{ Chitinase } & PR8, Chitinase 1 (Os10g0416500) & 4.12 & 2.49 & 1.62 & \multirow{5}{*}{$\begin{array}{l}\text { Schlumbaum et al. (1986), Mourão Filho et al. } \\
\text { (2014) }\end{array}$} \\
\hline & Chitinase 3 (Os06g0726100) & 3.97 & 1.52 & 2.44 & \\
\hline & Chitinase 8 (Os10g0542900) & 3.50 & 1.23 & 2.26 & \\
\hline & Chib3a (Os01g0660200) & 3.21 & 2.28 & - & \\
\hline & Chitinase 11 (Os03g0132900) & 2.88 & 1.97 & - & \\
\hline \multirow[t]{3}{*}{ Glucanase } & $\begin{array}{l}\text { Beta-1, 3-glucanase, pathogenesis-related protein } \\
2 \text { (Os01g0940700) }\end{array}$ & 3.71 & 2.90 & - & \multirow[t]{3}{*}{ Gerhard and Frederick (1999) } \\
\hline & beta-1, 3-glucanase 10 (Os01g0713200) & 3.58 & 2.50 & - & \\
\hline & beta-1, 3-glucanase 11 (Os07g0539100) & 2.44 & 2.15 & - & \\
\hline \multirow[t]{3}{*}{ PR10 } & $\begin{array}{l}\text { Root-specific Oryza sativa PR10, PR10a } \\
\text { (Os12g0555000) }\end{array}$ & 5.24 & 3.17 & 2.08 & \multirow[t]{3}{*}{ Takeuchi et al. (2016), Pulla et al. (2010) } \\
\hline & Jasmonate inducible PR10 (Os03g0300400) & 2.59 & 2.00 & - & \\
\hline & PR10B (Os12g0555200) & 4.10 & 3.00 & - & \\
\hline XB15 & XA21 binding protein15 (Os03g0821300) & 2.27 & 1.88 & - & Park et al. (2008) \\
\hline \multirow[t]{2}{*}{ AOS } & Allene oxide synthase 1 (Os03g0767000) & 2.39 & 1.90 & - & Gnanaprakash et al. (2013) \\
\hline & Allene oxide synthase 2 (Os03g0225900) & 5.59 & 2.93 & - & Pajerowska-Mukhtar et al. (2009) \\
\hline \multirow[t]{6}{*}{ Elicitor 5} & $\begin{array}{l}\text { E3 ubiquitin-protein ligase EL5 (Elicitor 5) } \\
\text { (Os02g0559800) }\end{array}$ & 4.84 & 3.20 & - & \multirow[t]{6}{*}{ You et al. (2016), Kumar et al. (2016) } \\
\hline & Elicitor 5 (Os02g0560200) & 4.79 & 3.20 & - & \\
\hline & Elicitor 5 (Os02g0560600) & 4.77 & 3.17 & - & \\
\hline & Elicitor 5 (Os02g0561000) & 4.80 & 3.18 & - & \\
\hline & Elicitor 5 (Os02g0561400) & 4.79 & 3.17 & - & \\
\hline & Elicitor 5 (Os02g0561800) & 4.82 & 3.21 & - & \\
\hline PAL & Phenylalanine ammonia lyase (Os05g0427400) & 3.33 & 2.95 & - & Tonnessen et al. (2015), Solekha et al. (2020) \\
\hline
\end{tabular}


Table 1 (continued)

\begin{tabular}{|c|c|c|c|c|c|}
\hline \multirow[t]{2}{*}{ Protein name } & \multirow[t]{2}{*}{ Description (gene ID) } & \multicolumn{3}{|c|}{$\log _{2}($ Fold Chang) $(P<0.05)$} & \multirow[t]{2}{*}{ References } \\
\hline & & $\begin{array}{l}\text { E48 } \\
\text { versus } \\
\text { Con0 }\end{array}$ & $\begin{array}{l}\text { E48 } \\
\text { versus } \\
\text { Con48 }\end{array}$ & $\begin{array}{l}\text { Con48 } \\
\text { versus } \\
\text { Con0 }\end{array}$ & \\
\hline \multirow[t]{7}{*}{ POD } & Class III peroxidase (POD) 19 (Os01g0787000) & 3.96 & 2.14 & 1.81 & \multirow{7}{*}{$\begin{array}{l}\text { Gao et al. (2010), Wally and Punja. (2010), } \\
\text { Takashima et al. (2013) }\end{array}$} \\
\hline & Class III POD22 (Os01g0963000) & 2.54 & 1.86 & - & \\
\hline & POD22.3 (Os07g0677200) & 3.41 & 1.61 & 1.79 & \\
\hline & Class III POD59 & 2.12 & 1.39 & - & \\
\hline & Class III POD62 (Os04g0688500) & 4.20 & 1.51 & 2.7 & \\
\hline & Class III POD81 (Os06g0522300) & 4.12 & 1.96 & - & \\
\hline & Class III POD83 (Os06g0521500) & 4.49 & 2.24 & - & \\
\hline \multirow[t]{3}{*}{ Myb } & $\begin{array}{l}\text { Myb transcription factor2 (Myb2) } \\
\text { (Os03g0315400) }\end{array}$ & 3.73 & 2.09 & 1.64 & Qi (2015) \\
\hline & Myb4 paralog (Os02g0624300) & 6.95 & 4.10 & - & Baldoni et al. (2013) \\
\hline & Myb4, Myb8 (Os04g0517100) & 5.21 & 3.39 & 1.82 & \\
\hline NPR & NPR1-like gene 4 (Os01g0837000) & 2.04 & 2.01 & - & Liu et al. (2005) \\
\hline
\end{tabular}

The italic font represents the genes used in qPCR validation in Fig. 8. " - represents $P>0.05$

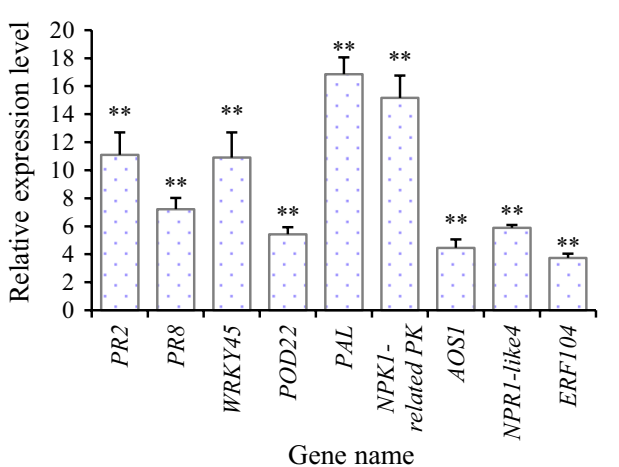

Fig. 8 PR genes with EsXA-induced up-regulated transcription levels. The italic font in Table 1 represents the genes used in QPCR validation; "**" above the column indicates the differences between $\mathrm{E} 48$ and Con48 were significant $(P<0.01)$

plant diseases and for the genetic improvement of rice to enhance disease resistance.

\section{Materials and Methods Materials}

The Fusarium oxysporum strain used in this study was preserved in our laboratory. The cultivated japonica rice model species Oryza sativa L. was purchased from Kyoto Co., Ltd. Japan. It was used as a typical japonica rice genome donor in the International Rice Genome Project, and its genome has been sequenced (Goff 2002). The EsxA exogenously expressed and secreted by $P$. pastoris cells was dissolved in $50 \mathrm{mM}$ PBS and stored at $-80^{\circ} \mathrm{C}$.
Induction of Rice Seedling Blight Resistance by EsxA Seed-Dipping Treatment

Sterile filter paper was added to six Petri dishes. Rice seeds were soaked in sterile water for 5 days at room temperature and then placed on the filter paper, with 100 seeds per Petri dish. Next, $10 \mathrm{~mL}$ EsxA solution $(10 \mu \mathrm{g} / \mathrm{mL}$; prepared in $50 \mathrm{mM}$ PBS, $\mathrm{pH} 7.5)$ was added to three Petri dishes, which were then gently shaken to ensure all seeds were fully soaked (marked as EsxA treatment). As the control, a bovine serum albumin (BSA) solution was added to the other three Petri dishes (marked as Con). All samples were incubated at $28{ }^{\circ} \mathrm{C}$ for $24 \mathrm{~h}$. Three biological replicate (three Petri dishes) were set for both of the Con and EsxA treatments, respectively.

When the radicles grew out (approximately $1 \mathrm{~cm}$ long), $5 \mathrm{~mL}$. oxysporum spore suspension $\left(1 \times 10^{6} / \mathrm{mL}\right)$ was added to all six Petri dishes, which were rotated to ensure all radicles were inoculated with spores. seedlings were incubated at $28^{\circ} \mathrm{C}$ for $48 \mathrm{~h}$ and then at room temperature with a 12-h light:12-h dark cycle.

At 4 and 8 days after the inoculation with $F$. oxysporum, the germination rate was determined by counting the number of sprouted seeds in every Petri dishes. Additionally, the representive seedlings were photographed and the bud length and root length of random 10 seedlings in every Petri dishes were measured. Average germination rate, bud length or root length in each Petri dish was as one of the three biological replicats for both of the Con and EsxA treatments, respecitively. The induction efficiency was calculated using Eq. 1. 


$$
\text { Induction efficiency }(\%)=\left(R_{t}-R_{c}\right) / R_{c} \times 100
$$

$R_{t}$ : germination rate of EsxA-treated seeds; $R_{c}$ : germination rate of control seeds.

\section{Seedling-dipping Treatment}

Rice seeds were soaked in sterile water for 5 days at room temperature and then placed on sterile filter paper in six Petri dishes, with 16 seeds per Petri dish. To maintain humid conditions, $10 \mathrm{~mL}$ distilled water was added to the Petri dishes, which were then incubated at $28^{\circ} \mathrm{C}$ for $24 \mathrm{~h}$. When the radicles grew out (approximately $1 \mathrm{~cm}$ long), $10 \mathrm{~mL}$ EsxA solution $(10 \mu \mathrm{g} / \mathrm{mL}$, prepared in $50 \mathrm{mM}$ PBS, $\mathrm{pH}$ 7.5) was added to three Petri dishes (marked as EsxA treatment), which were then gently shaken to ensure all seedlings were fully soaked. As the control, BSA was added to the other three Petri dishes (marked as Con treatment). The seedlings in all Petri dishes were incubated at $28{ }^{\circ} \mathrm{C}$ with a 12 -h light:12-dark cycle for $48 \mathrm{~h}$. Next, $5 \mathrm{~mL}$ F. oxysporum spore suspension $\left(1 \times 10^{6} / \mathrm{mL}\right)$ was added to all six Petri dishes, which were then rotated to ensure all seedlings were inoculated with spores. Samples were incubated at $28{ }^{\circ} \mathrm{C}$ for $48 \mathrm{~h}$ and then at room temperature with a 12-h light:12-dark cycle for 5 daysThe bud length and root length of all seedlings in each Petri dishs were measured. Average plant length or root length in each Petri dishes was as one of three biological replicates for both of the Con and EsxA treatments, respectively. The induction efficiency was calculated through germination rate, root length or bud length of seedlings using Eq. 2. Because rice seedling blight pathogen $F$. oxysporum can inject seeds and lead to seed rot, then the seeds can't germinate, so we calculated induction efficiency using germination rates; it can also inhibit rice buds and roots growing, so we calculated induction efficiency using bud length or root length.

$$
\text { Induction efficiency }(\%)=\left(R_{E s x A}-R_{C o n}\right) / R_{C o n} \times 100
$$

$R_{t}$ : rice germination rate, root length or bud length of EsxAtreatment; Rc: rice germination rate, root length or bud length of of Con treatment.

\section{Seedling-spraying Treatment}

Seedling culture: Rice seeds were soaked in sterile water for 5 days at room temperature and then placed on a sponge mat at the bottom of six plastic pots, with 200 seeds per pot. To maintain humid conditions, the sponge mat was moistened with $10 \mathrm{~mL}$ distilled water. Rice seedlings were incubated at $30{ }^{\circ} \mathrm{C}$ in darkness for 2 days and then at $25{ }^{\circ} \mathrm{C}$ with a 12 -h light:12-dark cycle for $48 \mathrm{~h}$ (plant length was approximately $1.5 \mathrm{~cm}$ and root length was approximately $2.5 \mathrm{~cm}$ ). Rice seedlings were sprayed with sterile water to maintain humid conditions for growth.

EsxA spray treatment and analysis of plant biological indices: Seedlings in three pots were sprayed with $20 \mu \mathrm{g} /$ mL EsxA solution, with $1 \mathrm{~mL}$ per pot (marked as EsxA treatment). As the control, the seedlings in the other three pots were sprayed with a BSA solution (marked as Con treatment). After a 48-h incubation, the remaining EsxA and BSA solutions in the pots were discarded, after which $10 \mathrm{~mL}$ sterile water was added to the pots.

Inoculation with $F$. oxysporum and analysis of biological indices: $48 \mathrm{~h}$ after EsxA treatment, seedlings in each of the six pots were dipped in $10 \mathrm{~mL}$ F. oxysporum spore suspension $\left(1 \times 10^{6} / \mathrm{mL}\right)$ for $5 \mathrm{~min}$. After removing excess spore suspension from the pots, $10 \mathrm{~mL}$ sterile water was added to each pot to keep humidity for rice seedlings growth. Following a 7-day incubation at room temperature $\left(15-20^{\circ} \mathrm{C}\right)$ under natural light, 20 seedlings were random sampled from each pot and analyzed (i.e., plant length, number of roots, root length, and number of white roots). Average plant length, number of roots, root length, or number of white roots of the 20 seedlings in each pot was as one of three biological replicates for both of the Con and EsxA treatments, respectively. The rest seedlings in pots were contined incubating for 7 days for the following analysis.

Analysis of the effect of EsxA on rice seedling blight resistance: At 14 days after the inoculation with $F$. oxysporum, all of the rice plants in each pot were examined, the number of rice seedlings exhibiting sheath rot and stem rot symptoms was recorded. Disease incidence of seedling blight which leaded to sheath rot and stem rot, and the EsxA induction efficency were analyzed using Eqs. 3 and 4 . For the caculation of disease incidence of seedling blight, all of the remained seedlings in each pot were observed to determin the the incidence rate of sheath rot and stem rot, and disease incidence of total 180 seedlings in each pot was as one of the three biological replicates.

$$
\begin{aligned}
& \text { Disease incidence }(\%) \\
& =(\text { number of infected plants/total number of plants }) \times 100 \\
& \text { Induction efficiency }(\%) \\
& =(\text { disease incidence of Con }- \text { disease incidence of EsxA }) / \\
& \quad \text { disease incidence of Con }
\end{aligned}
$$

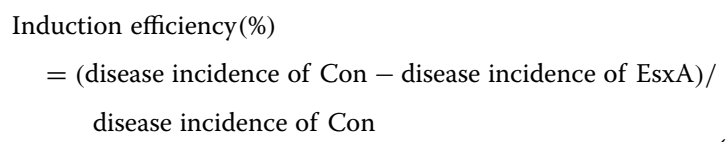

\section{Analysis of Rice Transcriptome RiceTreatment and Sampling for Transcriptome-sequencing Analysis}

Rice seeds were treated and seedlings were cultured as described in the above section. Seeds were sawn in nine pots. After emrgenced, rice seedlings were incubated in a 
greenhouse with a 12 -h light $\left(28^{\circ} \mathrm{C}\right): 12$-dark $\left(22^{\circ} \mathrm{C}\right)$ cycle for 7 days to produce enough biomass for sample analysis. At first, as the control, rice seedlings in each of the three pots were collected, respectively. Then the roots were cut off followed by being washed with distilled water, dried, and wrapped in tinfoil then quickly frozen in liquid nitrogen, plants (approximate $1 \mathrm{~g}$ ) collected from each pot was as one of the three biological replicate, respectively (marked as Con0). The frozen samples were stored at $-80^{\circ} \mathrm{C}$. At the same time, the seedlings in other three pots were sprayed with $20 \mu \mathrm{g} / \mathrm{mL}$ EsxA solution, with $1 \mathrm{~mL}$ per pot (marked as E48 treatment). As another control for that of $48 \mathrm{~h}$ after the EsxA treatment, the seedlings in the last three pots were sprayed with a BSA solution (marked as Con48). After $48 \mathrm{~h}$, seedlings were sampled randomly in each of the six pots (the three pots marked E48, and the another three pots marked with Con48), the roots of rice seedlings in each pot were cut off, and then the rice plants (approximate $1 \mathrm{~g}$ ) were washed with distilled water, dried, and wrapped in tinfoil, then quickly frozen in liquid nitrogen, plants sampled from each pot as one of the three biological replicates of E48 and Con0 treatments. The total nine samples (three biological replicates for each of the Con0, Con48 and E48 treatment) were sent to Bioengineering (Shanghai) Co., Ltd. in dry ice for a transcriptome sequencing analysis according a transcriptome sequencing projects with the reference genome for rice (Oryza sativa L.).

We extracted RNA from young seedlings that including sheaths and leaves but excluding roots, because we predicted that EsxA may induce systemic resistance in plant based on our previous studies and references, and to investigate whether EsxA can induce systemic resistance to seedling blight, but not the local resistance in roots.

The purpose of comparing E48 versus Con0 was to investigate which of the genes differentially expressed in rice induced by EsxA, were also differentially expressed without EsxA induction, but only changed over time (Con48 vs. Con0), and the extent to which they differentially express themselves, as well as which genes do not change their expression levels over time and are differentially expressed only when induced by EsxA.

\section{Transcriptome-sequencing and Analysis}

Rice total mRNA of the nine samples were isolated using E.Z.N.A. ${ }^{\circledR}$ Total RNA Kit (Qmega Bio-tek, Inc., GA, USA) according to the manufacturer's instructions, followd by RNase-free DNaseI treating to remove possible residual DNA; then mRNA library was constructed as the following processes: the mRNA fragmentation, double stranded cDNA synthesis, chemical modification of cDNA fragments, magnetic bead purification and fragmentation sorting, library amplification, detection and quality control, and the sequencing by Illumina Hiseq ${ }^{\mathrm{TM}}$ were performed successively.

After data evaluation and quality control using FastQC, short reads were mapped to the rice genome and annotated gene; sequences mapped to the genome were assembled using StringTie and then compared with known gene models using GFFCompare (version 0.10.1) to discover new transcription regions.

Expression level analysis was conducted usig StringTie (version 1.3.3b), and calculated $-\log _{2}$ (Fold Change), and expression difference analysis was performed using DESeq2 (version 1.12.4) in R Package and expression difference was statistic analyzed using DESeq (qValue $<0.05$, and $\mid$ FoldChange $\mid>2$ ). Volcano map was drawed based on the gene expression levels between treatmtments; Principal component analysis (PCA) was performed based on the gene expression level among treatmtments using vegan in R Package; and gene GO enrichment analysis was performed using topGO (version 2.24.0 in R Package), and scatter diagram of differentially expressed genes between treatments was maped based GO classification results using ggplot2 in $\mathrm{R}$ package.

\section{Verification of Up-regulated Genes in Rice by qPCR Primer Design}

Nine genes with up-regulated transcription revealed by the transcriptome sequencing data were selected, which had been reported as PR genes that can induce systemic resistance to diseases. The genes were analyzed by qPCR to check the transcriptome sequencing results were reliable, with the 18S rRNA gene used as the internal reference control. Total RNA was extracted from rice samples using the E.Z.N.A. ${ }^{\circledR}$ Total RNA Kit (Qmega Bio-tek, Inc., Shanghai, China). The primers used in this study are listed in Table 2.

\section{CDNA Synthesis}

After analyzing the extracted RNA by agarose gel electrophoresis, the RNA quality and concentration were determined using the SMA4000 microspectrophotometer [Merinton (Beijing) Instrument Co., Ltd., Beijing, China]. The high-quality RNA was reverse transcribed to synthesize cDNA. Briefly, $1500 \mathrm{ng}$ total RNA was added to a nuclease-free PCR tube in an ice bath, after which 1 $\mu \mathrm{L}$ Random Primer P (DN) 6 (100 pmol), $1 \mu \mathrm{L}$ dNTP Mix (0.5 mM final concentration), and RNase-free $\mathrm{ddH}_{2} \mathrm{O}$ was added for a final volume of $14.5 \mu \mathrm{L}$. After gently mixing, the reaction mixture was centrifuged for 3-5 s. It was then incubated at $65^{\circ} \mathrm{C}$ for $5 \mathrm{~min}$ and then in an ice bath for 2 min before centrifuging again for 3-5 s. Next, $4 \mu \mathrm{L} 5 \times$ RT Buffer, $0.5 \mu \mathrm{L}$ Ribolock RNase Inhibitor $(20$ $\mathrm{U})$ (Thermo Scientific), and $1 \mu \mathrm{L}$ Maxima Reverse Transcriptase (200 U) were added to the PCR tube, which was then gently mixed and centrifuged for $3-5 \mathrm{~s}$. The RNA 
Table 2 Primer details

\begin{tabular}{|c|c|c|}
\hline Gene name & Gene ID & Primer sequences \\
\hline \multirow[t]{2}{*}{$P R 2$} & Os01g0940700 & F:5'-ATTGGTCCTTGGAGTTGCG-3' \\
\hline & & R:5'-GATGCCGTTGGACTTGTAGAG-3' \\
\hline \multirow[t]{2}{*}{ PR8 } & Os10g0416500 & $\begin{array}{l}\text { F:5'-CAGCTACAAGTTTGAGTACGA } \\
\text { GACC-3' }\end{array}$ \\
\hline & & R:5'-CCAATCGGCACATAAGTCCA-3' \\
\hline \multirow[t]{2}{*}{ WRKY45 } & Os05g0322900 & Fn:5'-ATCTGGACGACATTATGGGTTT-3' \\
\hline & & $\begin{array}{l}\text { Rn:5'-GAGACGACACATCAACAA } \\
\text { GGAAT-3' }\end{array}$ \\
\hline \multirow[t]{2}{*}{ POD22 } & Os01g0963000 & F:5'-TGCTGAACACCAACGACAC-3' \\
\hline & & R:5'-CCATCTTGACGACGGAGTAGA-3' \\
\hline \multirow[t]{2}{*}{ PAL } & Os05g0427400 & F:5'-GACGGCAGGAAGGTGAAC-3' \\
\hline & & R:5'-GGTGAGGTGGTCGGTGTA-3' \\
\hline \multirow[t]{2}{*}{ NPK1-related PK } & Os01g0699600 & F:5'-ATGCTTCACAAGGAACCCAA-3' \\
\hline & & R:5'-GCCTTCTTCTACTTCGTCGTCT-3' \\
\hline \multirow[t]{2}{*}{ AOS1 } & Os03g0767000 & F:5'-GCTGGTGAAGAAGGACTACGA-3' \\
\hline & & R:5'-CCGCCGAACGAGTTGAAG-3' \\
\hline \multirow[t]{2}{*}{ NPR1-like5 } & Os01g0837000 & F:5'-GAGACCACAAGACTGCGTATGA-3' \\
\hline & & R:5'-CTGAGTTCCTTAGCAATCCCA-3' \\
\hline \multirow[t]{2}{*}{ ERF104 } & Os08g0474000 & Fn:5'-ATGGGAGGCAACCAGGAGTA-3' \\
\hline & & Rn:5'-GAGATGACATGGAGCAGCGT-3' \\
\hline \multirow[t]{2}{*}{ 18S rRNA } & & F:5'-CATAAACGATGCCGACCAG-3' \\
\hline & & R:5'-CACCACCCATAGAATCAAGAAA-3' \\
\hline
\end{tabular}

was reverse transcribed to cDNA in a thermal cycler under the following conditions: $25^{\circ} \mathrm{C}$ for $10 \mathrm{~min}, 50{ }^{\circ} \mathrm{C}$ for $30 \mathrm{~min}$, and $85{ }^{\circ} \mathrm{C}$ for $5 \mathrm{~min}$. The PCR tube was then stored at $-20{ }^{\circ} \mathrm{C}$.

\section{qPCR Analysis}

The cDNA samples were diluted 20 times and used as the template for a qPCR, which was completed using the StepOne Plus system (ABI, Foster, CA, USA) and the $2 \times$ SG Fast qPCR Master Mix. The $20 \mu \mathrm{L}$ reaction mixture included $10 \mu \mathrm{L}$ SG Fast qPCR Master Mix, 0.4 $\mu \mathrm{L}$ F primer $(10 \mu \mathrm{M}), 0.4 \mu \mathrm{L} R$ primer $(10 \mu \mathrm{M}), 7.2 \mu \mathrm{L} \mathrm{dd}_{2} \mathrm{O}$, and $2 \mu \mathrm{L}$ cDNA template. The qPCR program was as follows: $95^{\circ} \mathrm{C}$ for $3 \mathrm{~min}$; 45 cycles of $95^{\circ} \mathrm{C}$ for $5 \mathrm{~s}$ and $60{ }^{\circ} \mathrm{C}$ for $30 \mathrm{~s}$; dissociation according to instrument guidelines. The qPCR analysis was repeated three times.

\section{Data Analysis}

The SPSS 13.0 software (Chicago, USA) was used to evaluate the significance of the difference between two variables. A One-way ANOVA was performed for independent replicates of the same trial. The significant difference was determined at 0.05 levels and 0.01 levels. Paired-samples $\mathrm{T}$ test was conducted to detect whether the data violate the assumption. Bar graphs were prepared using Excel 2010.

\section{Abbreviations}

ABA: Abscisic acid; AOS: Allene oxide synthase; Elicitor 5: E3 ubiquitin-protein ligase EL5; HR: Hypersensitive response; ERF: Ethylene response factor; GO: Gene ontology; JA: Jasmonic acid; ISR: Induced systemic resistance; MAPK: Mitogen-activated protein kinase; MAPKKK: MAPK kinase kinase; MYB: V-myb avian myeloblastosis viral oncogene homolog; NPK: Nicotiana protein kinase; NPR: NPR1-like gene; PAL: Phenylalanine ammonia lyase; PK: Protein kinase; POD: Peroxidase; PR gene: Pathogenesis-related gene; qPCR: Quantitative real-time PCR; ROS: Reactive oxygen species; TIFY: Threonine-isoleucine-phenylalanine-tyrosin motif; WRKY: Transcriptor containing Tryptophan-ArginineLysine-Tyrosin conservative domain; XB: Xa21 binding protein.

\section{Supplementary Information}

The online version contains supplementary material available at https://doi. org/10.1186/s12284-021-00532-6.

Additional file 1. E48 vs Con0 and E48 vs Con48, which contains 1,376 differential transcribed genes between E48 and Con0, as well as 771 differential transcribed genes between E48 and Con48 with gene ID description, $\log _{2}$ Fold change and protein name.

\section{Acknowledgements}

Not applicable.

\section{Authors' Contributions}

WQY, WZL, and GPZ designed the study. WQY, PL, FCY, WXL, YW, ZQL, and WZL performed the experiments. WQY, WZL, and GPZ wrote the manuscript. All authors read and approved the manuscript.

\section{Funding}

This work was supported by the National Natural Science Foundation, China (32060633), the Natural Science Foundation of Heilongjiang Province, China (LH2019C080), and the Science and Technology Research Project of Education Department of Jiangxi Province, China (201714).

\section{Availability of Data and Materials}

All data generated or analyzed during this study are included in this article and its Additional file 1.

\section{Declarations}

Ethical Approval and Consent to Participate

Not applicable since the study did not involve animals and humans.

Consent for Publication

Not applicable as no data from any individual are used here.

\section{Competing interests}

Authors declare that they have no competing of interests.

\section{Author details}

${ }^{1}$ College of Life Sciences, Shangrao Normal University, Shanrao 334001, Jiangxi, China. ${ }^{2}$ Heilongjiang Academy of Land Reclamation Sciences, Harbin 150038, China. ${ }^{3}$ Heilongjiang Bayi Agricultural University, Daqing 163319 , Heilongjiang, China.

Received: 10 March 2021 Accepted: 20 October 2021

Published online: 04 November 2021

\section{References}

Baldoni E, Genga A, Medic A, Coraggio I, Locatelli F (2013) The OsMyb4 gene family: stress response and transcriptional auto-regulation mechanisms. Biol Plantarum 57:691-700

Berthet FX, Rasmussen PB, Rosenkrands I, Andersen P, Gicquel B (1998) A Mycobacterium tuberculosis operon encoding ESAT $=6$ and a novel 
low-molecular-mass culture filtrate protein (CFP-10). Microbiology 144:3195-3203

Cheng CH, Shen BN, Shang QW, Liu LYD, Peng KC, Chen YH, Chen FF, Hu SF, Wang YT, Wang HC, Wu HY, Lo CT, Lin SS (2018) Gene-to-gene network analysis of the mediation of plant innate immunity by the eliciting plant response-like 1 (Epl1) elicitor of Trichoderma formosa. Mol PlantMicrobe in 31:683-691

Cheplick S, Sarkar D, Bhowmik PC, Shetty K (2018) Improved resilience and metabolic response of transplanted blackberry plugs using chitosan oligosaccharide elicitor treatment. Can J Plant Sci 98:717-731

Chujo T, Miyamoto K, Shimogawa T, Shimizu T, Otake Y, Yokotani N, Nishizawa Y, Shibuya N, Nojiri H, Yamane H (2013) OsWRKY28, a PAMP-responsive transrepressor, negatively regulates innate immune responses in rice against rice blast fungus. Plant Mol Biol 82:23-37

Darwati I, Manohara D, Rohimatun R, Nurhayati H (2018) The application of biotic elicitor on Artemisia annua L. to increase artemisinin content. IOP Conf Ser Earth Environ Sci 102:012013

Foissner I (2000) In vivo imaging of an elicitor-induced nitric oxide burst in tobacco. Plant J 23:817-824

Fu J, Liu Q, Wang C, Liang J, Liu L, Wang Q (2017) ZmWRKY79 positively regulates maize phytoalexin biosynthetic gene expression and is involved in stress response. J Exp Bot 69:497-510

Gabriel MG, Milagro TM, Carlos DRJ (2015) The defence elicitor AsES causes a rapid and transient membrane depolarization, a triphasic oxidative burst and the accumulation of nitric oxide. Plant Physiol Biochem 97:443-450

Gao C, Wang Y, Liu G, Wang C, Yang JC (2010) Cloning of ten peroxidase (POD) genes from Tamarix Hispida and characterization of their responses to abiotic stress. Plant Mol Biol Rep 28:77-89

Gerhard L, Frederick M (1999) Functions and regulation of plant $\beta-1,3-$ Glucanases (PR-2). In: Datta S K, Muthukrishnan S (eds) Pathogenesisrelated proteins in plants. CRC Press LLC, Boca Raton, pp 49-76.

Gnanaprakash PH, Jogaiah S, Sreedhara AP, Prashanth GN, Shetty SH (2013) Association between accumulation of allene oxide synthase activity and development of resistance against downy mildew disease of pearl millet. Mol Biol Rep 40:6821-6829

Goff SA (2002) A draft sequence of the rice genome (Oryza sativa L. ssp. japonica). Science 296(5565):92-100

Hoang T, Aagaard C, Dietrich J, Cassidy J, Dolganov GM, Schoolnik LCV, Agger EM, Andersen P (2013) Esat-6 (esxa) and tb10.4 (esxh) based vaccines for pre- and post-exposure tuberculosis vaccination. PLoS ONE 8(12):80579

Hu YR, Dong QY, Yu DQ (2012) Arabidopsis WRKY46 coordinates with WRKY70 and WRKY53 in basal resistance against pathogen Pseudomonas syringae. Plant Sci 185-186:288-297

Hur YJ, Kim DH (2014) Overexpression of OsMAPK2 enhances low phosphate tolerance in rice and Arabidopsis thaliana. AJPS 5:452-462

Inoue H, Hayashi N, Matsushita A, Xinqiong L, Nakayama A, Sugano S, Jiang CJ, Takatsuji H (2013) Blast resistance of CC-NB-LRR protein Pb1 is mediated by WRKY45 through protein-protein interaction. Proc Natl Acad Sci 110:9577-9582

Knoth C, Ringler J, Dangl JL, Eulgem T (2007) Arabidopsis WRKY70 is required for full RPP4-mediated disease resistance and basal defense against Hyaloperonospora parasitica. Mol Plant-Microbe in 20:120-128

Kumar M, Lee SC, Yi J, Min HJ, Kim SR (2016) An ER localized E3 Ubiquitin ligase, OsATL5, is involved in cold, drought and disease resistance in rice. In: International conference of the genetics society of Korea

Li J, Brader G, Palva ET (2004) The WRKY70 transcription factor: a node of convergence for jasmonate-mediated and salicylate-mediated signals in plant defense. Plant Cell 16:319-331

Li SW, Nie HZ, Qiu DW, Shi MW, Yuan QH (2019a) A novel protein elicitor PeFOC1 from Fusarium oxysporum triggers defense response and systemic resistance in tobacco. Biochem Biophy Res Commun. https://doi. org/10.1016/j.bbrc.2019.05.018

Li L, Wang SC, Yang XF, Francis F, Qiu DW (2020) Protein elicitor PeaT1 enhanced resistance against aphid (Sitobion avenae) in wheat. Pest Manag Sci 76:236-243

Liu G, Holub EB, Alonso JM, Ecker JR, Fobert PR (2005) An arabidopsis NPR1-like gene, NPR4, is required for disease resistance. Plant J 41:304-318

Liu X, Bai X, Wang X, Chu C (2007) OsWRKY71, a rice transcription factor, is involved in rice defense response. J Plant Physiol 164:969-979
Liu J, Chen X, Liang X, Zhou X, Yang F, Liu J, He SY, Guo Z (2016) Alternative splicing of rice WRKY 62 and WRKY76 transcription factor genes in pathogen defense. Plant Physiol 171:1427-1442

Liu J, Liu B, Chen S, Gong BQ (2018) A tyrosine phosphorylation cycle regulates fungal activation of a plant receptor Ser/Thr kinase. Cell Host Microbe 23:241-253

Ma Y, Keil V, Sun J (2015) Characterization of mycobacterium tuberculosis EsxA membrane insertion: roles of $\mathrm{N}$ - and C-terminal flexible arms and central helix-turn-helix motif. J Biol Chem 290:7314-7322

Ma H, Chen J, Zhang Z, Ma L, Yang Z, Zhang Q, Li X, Xiao J, Wang S (2017) MAPK kinase 10.2 promotes disease resistance and drought tolerance by activating different MAPKs in rice. Plant J 92:557-570

Ma H, Li J, Ma L, Wang P, Xue Y, Yin P, Xiao J, Wang S (2021) Pathogen-inducible OsMPKK10.2-OsMPK6 cascade phosphorylates the RAF-like kinase OsEDR1 and inhibits its scaffold function to promote rice disease resistance. Mol Plant. https://doi.org/10.1016/j.molp.2021.01.008.

Mao J, Liu Q, Yang X, Long C, Zhao M, Zeng H, Liu H, Yuan J, Qiu D (2010) Purification and expression of a protein elicitor from Alternaria tenuissima and elicitor-mediated defense responses in tobacco. Ann Appl Biol 156:411-420

Meng Y, Wise RP (2012) HvWRKY10, HvWRKY19, and HvWRKY28 regulate Mla-triggered immunity and basal defense to barley powdery mildew. Mol Plant Microbe in 25:1492-1505

Miao Y, Zentgraf $\mathrm{U}$ (2007) The antagonist function of arabidopsis WRKY53 and ESR/ESP in leaf senescence is modulated by the jasmonic and salicylic acid equilibrium. Plant Cell 19:819-830

Molan YY, El-Komy MH (2010) Expression of SI-WRKY1 transcription factor during B. cinerea tomato interaction in resistant and susceptible cultivars. Int J Plant Breed Genet 4:1-12

Mourão Filho FAA, Stipp LCL, Beltrame AB, Boscariolcamargo RL, Harakava R, Mendes B (2014) Genetic transformation of sweet orange to overexpress a CsPR-8 gene aiming for Candidatus Liberibacter asiaticus resistance. J Citrus Pathol. https://doi.org/10.5070/C411025270

Pajerowska-Mukhtar K, Stich B, Achenbach U, Ballvora A, Lubeck J, Strahwald J, Tacke E, Hofferbert HR, Ilarionova E, Bellin D (2009) Single nucleotide polymorphisms in the allene oxide synthase 2 gene are associated with field resistance to late blight in populations of tetraploid potato cultivars. Genetics 181:1115-1127

Park CJ, Peng Y, Chen XW (2008) Rice XB15, a protein phosphatase 2C, negatively regulates cell death and XA21-mediated innate immunity. PLoS Biol 6:e231

Pollock JM, Andersen P (1997) The potential of the ESAT-6 antigen secreted by virulent Mycobacteria for specific diagnosis of tuberculosis. I Infect Dis 175:1251-1254

Pré M, Atallah M, Champion A, Vos MD, Memelink J (2008) The AP2/ERF domain transcription factor ORA59 integratesjasmonic acid and ethylene signals in plant defense. Plant Physiol 147:1347-1357

Pulla RK, Lee OR, In JG, Kim J, Senthil K, Yang DC (2010) Expression and functional characterization of pathogenesis-related protein family 10 gene, PgPR10-2, from Panax ginseng CA Meyer. Physiol Mol Plant Pathol 74:323-329

Qi LJ (2015) Functional validation of MYB2, MYB7 and MYB8 genes in Scutellaria baicalensis and cloning of WRKY gene in tobacco. Wuhan Polytechnic University. Chinese Doctoral Dissertation with English abstract

Qiu DW, Mao JJ, Yang XF, Zeng HM (2009) Expression of an elicitor-encoding gene from Magnaporthe grisea enhances resistance against blast disease in transgenic rice. Plant Cell Rep 28:925-933

Ruiz C, Nadal A, Montesinos E, Pla M (2018) Novel Rosaceae plant elicitor peptides as sustainable tools to control Xanthomonas arboricola pv. pruni in Prunus spp. Mol Plant Pathol 19:418-431

Savatin DV, Bisceglia NG, Marti L, Fabbri C, Cervone F, Lorenzo GD (2014) The Arabidopsis NUCLEUS-AND PHRAGMOPLAST-LOCALIZED KINASE1related protein kinases are required for elicitor-induced oxidative burst and immunity. Plant Pysiol. https://doi.org/10.1104/pp.114.236901

Schlumbaum A, Mauch F, Vögeli U, Boller T (1986) Plant chitinases are potent inhibitors of fungal growth. Nature 324:365-367

Schulthess B, Bloes DA, Berger-Bächi B (2012) Opposing roles of $\sigma^{B}$ and $\sigma$ ${ }^{B}$-controlled SpoVG in the global regulation of esxA in Staphylococcus aureus. BMC Microbiol 12:17 
Shen Y, Li J, Xiang J, Wang JQ (2019) Isolation and identification of a novel protein elicitor from a Bacillus subtilis strain BU412. AMB Express 9:117. https://doi.org/10.1186/s13568-019-0822-5

Shimono M, Sugano S, Nakayama A, Jiang CJ, Ono K, Takatsuji TH (2007) Rice WRKY45 plays a crucial role in benzothiadiazole-inducible blast resistance. Plant Cell 19:2064-2076

Solekha R, Susanto FA, Joko T, Nuringtyas TR, Purwestri YA (2020) Phenylalanine ammonia lyase (PAL) contributes to the resistance of black rice against Xanthomonas oryzae pv. oryzae. J Plant Pathol 102:359-365

Song F, Goodman RM (2002) OsBIMK1, a rice MAP kinase gene involved in disease resistance responses. Planta 215:997-1005

Takashima Y, Suzuki M, Ishiguri F, lizuka K, Yoshizawa N, Yokota S (2013) Cationic peroxidase related to basal resistance of Betula platyphylla var. japonica plantlet No.8 against canker-rot fungus Inonotus obliquus strain IO-U1. Plant Biotechnol-NAR 30:199-205

Takeuchi K, Hasegawa H, Gyohda A, Komatsu S, Okamoto T, Okada K, Terakawa T, Koshiba T (2016) Overexpression of RSOsPR10, a root-specific rice PR10 gene, confers tolerance against drought stress in rice and drought and salt stresses in bentgrass. Plant Cell Tiss Org 127:1-12

Tonnessen BW, Manosalva P, Lang JM, Baraoidan M, Bordeos A (2015) Rice phenylalanine ammonia-lyase gene OsPAL4 is associated with broad spectrum disease resistance. Plant Mol Biol 87:273-286

Tripathi S, Srivastava Y, Sangwan RS, Sangwan NS (2020) In silico mining and functional analysis of AP2/ERF gene in Withania somnifera. Sci Rep-UK 4877:10. https://doi.org/10.1038/s41598-020-60090-7

Ülker B, Mukhtar MS, Somssich IE (2007) The WRKY70 transcription factor of Arabidopsis influences both the plant senescence and defense signaling pathways. Planta 226:125-137

Ulrichs T, Munk ME, Mollenkopf H, Behr Perst S, Colangeli R, Gennaro MLURA, Kaufmann SHE (1998) Differential T cell responses to Mycobacterium tuberculosis ESAT6 in tuberculosis patients and healthy donors. Eur J Immunol 28:3949-3958

Wally O, Punja ZK (2010) Enhanced disease resistance in transgenic carrot (Daucus carota L.) plants over-expressing a rice cationic peroxidase. Planta 232:1229-1239

Wang B, Yang X, Zeng H, Liu H (2012) The purification and characterization of a novel hypersensitive-like response-inducing elicitor from Verticillium dahliae that induces resistance responses in tobacco. Appl Microbiol Biot 93:191-201

Wang D, Liu B, Ma Z, Feng J, Yan H (2021) Reticine a, a new potent natura elicitor: isolation from the fruit peel of citrus reticulate and induction of systemic resistance against tobacco mosaic virus and other plant fungal diseases. Pest Manag Sci 77:354-361

Yang B, Jiang Y, Rahman MH, Deyholos MK, Kav NNV (2009) Identification and expression analysis of WRKY transcription factor genes in canola (Brassica napus L.) in response to fungal pathogens and hormone treatments. BMC Plant Biol 9:68. https://doi.org/10.1186/1471-2229-9-68

Ye HY (2011) Expression profling analysisof rice genes under cold stress and characterization of stress-related TIFY genes in rice. Huazhong
Agricultural University. Chinese Doctoral Dissertation with English abstract

Ye H, Du H, Tang N, Li X, Xiong L (2009) Identification and expression profiling analysis of TIFY family genes involved in stress and phytohormone responses in rice. Plant Mol Biol. https://doi.org/10.1007/ s11103-009-9524-8

Yi YY, Wang HQ, Su LL, Wang H, Zhang BJ, Su Y (2021) A comparative investigation on the role and interaction of EsxA and EsxB in host immune response. Microb Pathog 154:104843. https://doi.org/10.1016/j.micpath. 2021.104843

Yokotani N, Shikata M, Ichikawa H, Mitsuda N, Ohme-Takagi M, Ohme-Takagi M, Minami E, Nishizawa Y (2018) OsWRKY24, a blast-disease responsive transcription factor, positively regulates rice disease resistance. J Gen Plant Pathol 84:85-91

You Q, Zhai K, Yang D, Yang W, Wu J, Liu J, Pan W, Wang J, Zhu X, Jian Y (2016) An E3 ubiquitin ligase-BAG protein module controls plant innate immunity and broad-spectrum disease resistance. Cell Host Microbe 20:758-769

Yu WQ (2019) Promoting-growth and defending-diseases mechanism of Paenibacillus terrae NK3-4 in Paddy Rice. Heilongjiang Bayi Agricultural University. Chinese Doctor Dissertation with an English article

Yu WQ, Liu WZ, Yan FC, Li HY, Zheng GP, Li DP, Zheng AB, Zhao TT, Jiang $\mathrm{H}_{\text {, }}$ He D, Yan BW, Sui WZ, Wang P (2021a) Application of Paenibacillus terrae protein EsXA as a biological control agent to controlling rice blast. China Patent: ZL201811372700.8, 3 Mar 2021.

Yu WQ, Wang X, Tang YC, Yan FC, LiuWZ ZGP, Yin DM (2021b) Cloning and expression of the EsxA gene and the growth-promoting effects of the encoded protein on rice seedlings. AMB Express 11(1):72. https://doi.org/ 10.21203/rs.3.rs-97808/v1

Zhao J, Davis LC, Verpoorte R (2005) Elicitor signal transduction leading to production of plant secondary metabolites. Biotechnol Adv 23:283-333

Zhao KX, Chu SS, Zhang XD, Wang LP, Rono JK, Yang ZM (2019) AtWRKY21 negatively regulates tolerance to osmotic stress in Arabidopsis. Environ Exp Bot 169:103920

Zhou QY, Tian AG, Zou HF, Xie ZM, Lei G, Huang J, Wang CM, Wang HW, Zhang JS, Chen SY (2008) Soybean WRKY-type transcription factor genes, GmWRKY13, GmWRKY21, and GmWRKY54, confer differential tolerance to abiotic stresses in transgenic Arabidopsis plants. Plant Biotechnol J 6:486-503

Zhou H, Du H, Zhang H, Shen H, Yan R, He Y, Wang M, Zhu X (2013) EsxA might as a virulence factor induce antibodies in patients with Staphylococcus aureus infection. Braz J Microbiol 44:267-271

\section{Publisher's Note}

Springer Nature remains neutral with regard to jurisdictional claims in published maps and institutional affiliations.

\section{Submit your manuscript to a SpringerOpen ${ }^{\circ}$ journal and benefit from:}

- Convenient online submission

- Rigorous peer review

- Open access: articles freely available online

- High visibility within the field

- Retaining the copyright to your article

Submit your next manuscript at springeropen.com 